\title{
Apolipoprotein E genotype and hepatitis C, HIV and herpes simplex disease risk: a literature review
}

\author{
Inga Kuhlmann ${ }^{1}$, Anne Marie Minihane ${ }^{2}$, Patricia Huebbe ${ }^{1}$, Almut Nebel ${ }^{3}$, Gerald Rimbach ${ }^{1 *}$
}

\begin{abstract}
Apolipoprotein $\mathrm{E}$ is a polymorphic and multifunctional protein with numerous roles in lipoprotein metabolism. The three common isoforms apoE2, apoE3 and apoE4 show isoform-specific functional properties including different susceptibilities to diseases. ApoE4 is an accepted risk factor for Alzheimer's disease and cardiovascular disorders. Recently, associations between apoE4 and infectious diseases have been demonstrated. This review summarises how apoE4 may be involved in the infection incidence and associated pathologies of specific infectious diseases, namely hepatitis $C$, human immunodeficiency virus disease and herpes simplex.

ApoE4 seems to be protective against chronic hepatitis $C$ virus infection and retards fibrosis progression. In contrast apoE4 enhances the fusion rate of human immunodeficiency virus with target cell membranes, resulting in accelerated cell entry and faster disease progression. Its association with human immunodeficiency virus-associated dementia remains controversial. Regarding herpes simplex virus infection, apoE4 intensifies virus latency and is associated with increased oxidative damage of the central nervous system, and there is some evidence that herpes simplex virus infection in combination with the apoE4 genotype may be associated with an increased risk of Alzheimer's disease. In addition to reviewing available data from human trials, evidence derived from a variety of cell culture and animal models are considered in this review in order to provide mechanistic insights into observed association between apoE4 genotype and viral disease infection and pathology.
\end{abstract}

\section{Introduction}

Viral diseases are a global health problem. Like many other diseases, differences in the pathological features and outcome of viral diseases exist, which are undoubtedly in part due to genetic variations in the host. Apolipoprotein $\mathrm{E}$ (apoE), in addition to being a central mediator of lipoprotein metabolism, has an ever increasing 'repertoire' of biological functions [1,2]. As will be reviewed here, accumulating evidence indicates that apoE genotype could be an important host genetic factor affecting infectious disease risk.

\section{ApoE tissue sources and functions}

The mature apoE protein results from the proteolytic cleavage of a 317-amino acid precursor protein and contains 299 amino acids with a molecular weight of approximately $34 \mathrm{kDa}$ [3]. ApoE is synthesised primarily

\footnotetext{
* Correspondence: rimbach@foodsci.uni-kiel.de

${ }^{1}$ Institute of Human Nutrition and Food Science, Christian-AlbrechtsUniversity, Hermann-Rodewald-Strasse 6, 24098 Kiel, Germany
}

by the liver. It is estimated that $20-40 \%$ of total apoE is produced by extrahepatic tissues with the brain glial cells and macrophages expressing relatively high amounts, with lesser amounts produced by the kidneys, adrenals, spleen, testis and the skin [4-7]. In the circulation apoE is mainly found in the lipoprotein bound form, present in chylomicrons (CM), very low density lipoproteins (VLDL), and high density lipoproteins (HDL), at a plasma concentration of 20-60 $\mathrm{mg} / \mathrm{l}$ [7].

The most well described role of apoE to-date is as a regulator of multiple steps in lipid (cholesterol and triglyceride) and lipoprotein metabolism, including VLDL synthesis and secretion, the hydrolysis of VLDL to produce low density lipoproteins (LDL) and the receptor mediated removal of triglyceride-rich lipoprotein remnants (VLDL and CM remnants) by the liver $[7,8]$. In addition to the systemic transport and uptake of lipoproteins, apoE is recognised as the primary shuttle protein for lipids which either enters the brain and central nervous system (CNS) via the blood-brain barrier or is 
endogenously synthesised [9], and also for the removal of modified lipids for excretion [10].

ApoE regulates the delivery of cholesterol and other lipids to target cells by acting as a high affinity ligand for multiple members of the LDL receptor family including the LDL receptor (LDL-R), the LDL receptorrelated protein (LRP), the scavenger receptor, the VLDL receptor, and the apoE receptor 2 [11].

In addition, apoE binds to cell surface located glycosaminoglycans such as heparin sulphate proteoglycans (HSPG) [12,13] with lipoprotein uptake facilitated by either HSPG alone or an HSPG-LRP complex [12].

\section{ApoE genotype}

The widely studied human apoE gene is located on chromosome 19, closely linked to the apoC-I/C-II gene complex $[6,14,15]$. To-date 72 individual single nucleotide polymorphisms (SNPs) of the human apoE gene have been identified [16]. The two SNPs rs429358 (C/T) and rs7412 $(\mathrm{C} / \mathrm{T})$ [16] determine together the three major alleles, termed Epsilon-2, Epsilon-3 and Epsilon-4. The corresponding products of these alleles, the apoE2, apoE3 and apoE4 protein isoforms, differ only by a single amino acid at two residues. ApoE3 has cysteine at residue 112 (rs429358) and arginine at residue 158 (rs7412), while apoE2 contains cysteine and apoE4 arginine at both positions $[17,18]$. Additionally, two minor alleles of the gene, $\varepsilon 1$ and $\varepsilon 5$, exist but these are present in less than $0.1 \%$ of the population [19]. The three major alleles are responsible for three homozygous $(\varepsilon 2 /$ $\varepsilon 2, \varepsilon 3 / \varepsilon 3, \varepsilon 4 / \varepsilon 4)$ and three heterozygous $(\varepsilon 2 / \varepsilon 3, \varepsilon 2 / \varepsilon 4$, $\varepsilon 3 / \varepsilon 4)$ genotypes $[17,18]$.

The amino acid substitutions affect salt bridge formation within the proteins, which ultimately impacts on lipoprotein preference, stability of the protein and on receptor binding activities of the isoforms [2,7] as shown in table 1 . Overall apoE4 has a comparable or slightly higher affinity for the LDL-R relative to the apoE3 form, with apoE2 binding with less than two percent of the affinity of apoE3 [20].

ApoE genotype, blood lipid levels and risk of cardiovascular disease and Alzheimer's disease

The $\varepsilon 4$ allele occurs in approximately $14 \%$ of the general German population, but its frequency decreases significantly with age, dropping to about $5 \%$ in centenarians [21]. Thus, it is a major mortality factor in the elderly, supposedly via its predisposition to both Alzheimer and cardiovascular diseases [22,23].

The physiological and molecular mechanisms of the associations between apoE genotype and fasting and non-fasting lipid levels are complex, and have been reviewed previously (see [7]). In general apoE4 carriers have a tendency for 5-10\% higher fasting total cholesterol, LDL-cholesterol and triglyceride levels relative to homozygote $\varepsilon 3 / \varepsilon 3[7,24]$. This tendency towards higher lipid levels is likely to be in part responsible for the 40$50 \%$ greater cardiovascular disease (CVD) risk in $\varepsilon 4$ carriers [25,26]; however additional mechanisms such as differences in oxidative status and chronic inflammation between apoE3 and apoE4 carriers may contribute to the observed differences in the CVD risk [8].

Although the molecular basis of the pathology is poorly understood, and likely to be in part due to apoE genotype associated differences in brain lipid metabolism, an apoE4 genotype has been highly consistently associated with the risk of an age-related loss of cognitive function, in an allele dose fashion. In a meta-analysis of the AlzGene database, Bertram and colleagues [27] reported odds ratios (OR) of Alzheimer's disease (AD) in Caucasians of 4.3 (95\% CI 3.3-5.5) and 15.6 (95\% CI 10.9-22.5) in $\varepsilon 3 / \varepsilon 4$ and $\varepsilon 4 / \varepsilon 4$ subgroups relative to the common $\varepsilon 3 / \varepsilon 3$ genotype, which was consistent with the findings of an earlier meta-analysis [28].

\section{Additional roles of apoE as a modulator of immune}

\section{function}

Lipoproteins, including apoE-containing lipoproteins, have the ability to modulate key elements of the immune response by either inhibiting or stimulating antigen and mitogen induced $\mathrm{T}$-lymphocyte activation as well as proliferation [29]. ApoE interacts with signals from multiple mitogens including transferrin and interleukin 2 (IL-2). Proliferation of both CD4 and CD8 lymphocytes is suppressed by apoE reducing the production of biologically active IL-2 [30]. In association with its immunomodulatory properties [31-33], apoE has an impact on the pathology of infectious diseases. Furthermore, recent research has demonstrated isoform-specific susceptibility to several viral infections $[2,8]$.

The present review article summarises the impact of the $\varepsilon 4$ allele on the susceptibility to specific infectious

Table 1 ApoE isoform amino acid differences and resulting chemical and physiological changes (according to Mahley and Rall [2], Minihane et al. [7])

\begin{tabular}{|c|c|c|c|c|c|}
\hline Isoform & Amino acid 112 & Amino acid 158 & Relative charge & Lipoprotein preference & LDL receptor binding affinity \\
\hline apoE2 & cysteine & cysteine & 0 & HDL & low \\
\hline apoE3 & cysteine & arginine & +1 & $\mathrm{HDL}$ & high \\
\hline apoE4 & arginine & arginine & +2 & VLDL, chylomicrons & high \\
\hline
\end{tabular}


virus diseases, namely hepatitis $\mathrm{C}$, human immunodeficiency virus (HIV) disease and herpes simplex. Furthermore, $\varepsilon 4$ allele frequencies in different populations around the world are described. Potential mechanisms underlying the protective or adverse effects of the apoE isoforms in these specific virus diseases are given. We also discuss the prevalence of the $\varepsilon 4$ allele in different global populations as well as the relationship between a higher frequency in certain regions and a possible protective effect of the apoE4 isoform on commonly encountered viral infections.

\section{ApoE4 allele frequencies in different populations}

The frequencies of the apoE alleles vary between different ethnicities. The $\varepsilon 3$ allele is usually the most prevalent, present in $50-90 \%$ of individuals, whereas $\varepsilon 2$ has the lowest frequency at $0-15 \%$, and is even absent in some native populations. The $\varepsilon 4$ allelic variant occurs at a frequency of $5-30 \%$ [34].

In Europe the $\varepsilon 4$ allele has a lower frequency in the southern rather than in the northern countries with continuously increasing frequencies with increasing latitude. The geographical decline from $\sim 20 \%$ in Finland [35] to $\sim 8 \%$ in Italy [36] and Greece [37] is likely to contribute to the north-south gradient in the prevalence of cardiovascular diseases [7,38,39]. In addition, $\varepsilon 4$ tends to be less frequent in Eastern Europe. For example, $\sim 11 \%$ of the Polish population carry an $\varepsilon 4$ allele [40], while the proportion is $\sim 14-15 \%$ in Germany and the Netherlands [41,42]. However, differences in $\varepsilon 4$ allele frequency are also evident within a population depending on ethnicity or geographical position. For instance, $8.5 \%$ of the individuals living in central Italy carry an $\varepsilon 4$ allele, while the proportion is slightly lower in southern Italy with $8.3 \%$ but only $5.3 \%$ in Sardinia, an island approximately $250 \mathrm{~km}$ west of the Italian mainland [36].

Remarkably, the highest frequencies of $\varepsilon 4$ are found in indigenous populations and those with a recent history of hunter gatherer lifestyle whereas long-established agricultural communities (such as those in the Middle East, southern Europe, in Southeast Asia and Central America) show the lowest frequencies [38]. African populations exhibit a two to three times higher frequency than populations from Central Europe. About $37 \%$ of native Africans living in South Africa carry the $\varepsilon 4$ allele [43]. The highest apoE4 frequency among populations of northern Europe and North America was found in Inuit from the eastern part of Greenland with $23 \% \varepsilon 4$ carriers [34]. The proportion of $\varepsilon 4$ observed in Aborigines (26\%) is twice as high as that in Australians of European descent (11\%) [44,45]. Aceves et al. [46] observed a heterogeneous $\varepsilon 4$ frequency in Mexicans, depending on the area's status of urbanisation as well as on the proportion of European gene flow, particularly that from Spanish colonisers. In Guadalajara, the second largest metropolitan area of Mexico with a relatively high proportion of Spanish descent habitants, the $\varepsilon 4$ frequency was lowest at $8.4 \%$, increased in the adjoining state Nayarit and reached its highest frequency of $28 \%$ in the Huichol Indians, a native Mexican population [46].

\section{Hepatitis C}

Hepatitis $\mathrm{C}$ virus (HCV) infection is a major global health problem with more than 170 million infected people worldwide [47]. The consequences of HCV infection vary, as some newly infected individuals develop minor or no liver damage and recover spontaneously by clearing the virus [48], whereas approximately $85 \%$ suffer from progressive chronic hepatitis $C$, which is the leading cause of cirrhosis and hepatocellular carcinoma in the Western world [49,50]. Approximately 20-25\% of $\mathrm{HCV}$ patients develop liver cirrhosis [51]. Accepted host factors for chronic $\mathrm{HCV}$ infection and progression of fibrosis and cirrhosis are older age at infection, male gender, excessive consumption of alcohol, insulin resistance, and the duration of infection [52,53]. In addition, a relationship between $\mathrm{HCV}$ and lipid metabolism has recently been suggested, since serum cholesterol levels are lower in patients with chronic HCV than in appropriately matched controls [54].

After infection, HCV circulates in the blood in a complex with lipoproteins. In the initial phase of infection, $\mathrm{HCV}$ virions are mainly associated with LDL, while later in the course of infection they are detectable in an assembly with HDL $[39,55]$. Attachment to hepatocytes is facilitated by binding of $\mathrm{HCV}$ envelope glycoprotein E2 to HSPG [56] with entry site of HCV into hepatocytes mainly via the LDL-R [57]. Due to the fact that both $\mathrm{HCV}$ and apoE bind to LDL-R and scavenger receptor [53] and that the apoE genotype affects receptor binding including a decreased number of LDL-R in apoE4 [58], it may be hypothesised that the apoE genotype impacts on $\mathrm{HCV}$ pathology. An overview of studies concerning the impact of apoE isoforms on HCV infection, outcome and course of disease in humans is presented in table 2 .

Wozniak et al. [48] investigated the association between apoE genotype and outcome of a HCV infection among $\mathrm{HCV}$ patients with chronic infection (defined as having detectable HCV RNA in the serum) or cleared infection (defined as presence of anti-HCV antibodies but absence of viral RNA in the serum). The apoE allele frequencies in the HCV infected groups were similar to those in the control group, with no differences between the HCV RNA-positive group and the negative individuals. In contrast, Price et al. [53] found a significantly lower number of subjects homozygous for 
Table 2 Effects of an apoE4 genotype on hepatitis C virus (HCV) infection and outcome in humans

\begin{tabular}{|c|c|c|c|}
\hline Reference & Subjects and profile & Parameter & Outcome \\
\hline Wozniak et al. 2002 [48] & $\begin{array}{l}156 \mathrm{HCV} \text { patients: } 111 \text { chronically infected and } 45 \text { with cleared } \\
\text { infection, and } 104 \text { non-HCV infected patients }\end{array}$ & $\begin{array}{l}\text { - risk of HCV infection } \\
\text { - risk of severe liver disease caused } \\
\text { by chronic HCV infection } \\
\text { - risk of non-HCV associated liver } \\
\text { diseases and extent of disease }\end{array}$ & $\begin{array}{l}\varepsilon 2=\varepsilon 3=\varepsilon 4 \\
\text { non }-\varepsilon 4>\varepsilon 4 \\
\varepsilon 2=\varepsilon 3=\varepsilon 4\end{array}$ \\
\hline $\begin{array}{l}\text { Mueller et al. } 2003 \\
\text { [60] }\end{array}$ & 506 chronically infected HCV patients & $\begin{array}{l}\text { response to antiviral treatment of } \\
\mathrm{HCV} \text { infection }\end{array}$ & non- $\varepsilon 4>\varepsilon 4$ \\
\hline Price et al. 2006 [53] & $\begin{array}{l}420 \text { Caucasian HCV patients: } 312 \text { chronically infected and } 108 \text { with } \\
\text { cleared infection, and } 288 \text { healthy controls }\end{array}$ & risk of chronic HCV infection & $\varepsilon 3>\varepsilon 4>\varepsilon 2$ \\
\hline $\begin{array}{l}\text { Mueller et al. } 2007 \\
\text { [59] }\end{array}$ & $\begin{array}{l}701 \mathrm{HCV} \text { patients chronically infected, } 523 \text { healthy controls, and } \\
283 \text { patients with non-HCV associated liver diseases }\end{array}$ & $\begin{array}{l}\text { - risk of chronic HCV infection } \\
\text { - risk of severe non-HCV associated } \\
\text { liver disease }\end{array}$ & $\begin{array}{l}\text { non- } \varepsilon 4>\varepsilon 4 \\
\varepsilon 4=\text { non- } \varepsilon 4\end{array}$ \\
\hline
\end{tabular}

HCV: hepatitis C virus

$\varepsilon 2$ in Caucasian hepatitis $\mathrm{C}$ patients compared to healthy controls, indicating a protective effect against $\mathrm{HCV}$ infection of the apoE $\varepsilon 2 / \varepsilon 2$ genotype [53]. In addition, risk of developing a chronic HCV infection was highest in the $\varepsilon 3 / \varepsilon 3$ genotype with odds ratio of 0.39 and 0.59 for the $\varepsilon 2$ and $\varepsilon 4$ allele, respectively, supporting the hypothesis that these genotypes are favouring viral clearance [53].

The association between severity of $\mathrm{HCV}$-induced liver damage and apoE genotype was also examined revealing significantly lower $\varepsilon 4$ allele frequencies in patients with severe versus mild inflammation and fibrosis [48] and a reduced risk of viral persistence [53] and chronic infection [59] in apoE4 carriers, suggesting that apoE4 protects $\mathrm{HCV}$ infected patients from developing severe liver disease. However, no significant impact of apoE genotype on non-HCV associated liver disease has been established [48,59].

Interestingly, response to antiviral treatment was higher in chronic $\mathrm{HCV}$-patients with an $\varepsilon 3 / \varepsilon 3$ genotype than with an $\varepsilon 3 / \varepsilon 4$ and $\varepsilon 4 / \varepsilon 4$ genotype [60].

Possible mechanisms of the impact of apoE4 on hepatitis C

Although several studies emphasise an impact of the apoE genotype on the course of $\mathrm{HCV}$ infection as well as on the outcome of $\mathrm{HCV}$ related liver damage, the underlying mechanisms of apoE-HCV-interactions remain to be elucidated. A summary of proposed mechanisms is given in figure 1 .

Chang et al. [49] investigated the properties of $\mathrm{HCV}$ virions and the role of apoE in $\mathrm{HCV}$ infectivity and virus production in an in vitro study using human hepatoma cell lines that stably produce infectious $\mathrm{HCV}$. Low-density HCV virions ( 1.08 to $1.12 \mathrm{~g} / \mathrm{ml}$ ) were found to be infectious whereas the majority of $\mathrm{HCV}$ RNA-containing particles emerging in higher-density fractions $(1.15$ to $1.21 \mathrm{~g} / \mathrm{ml})$ were poorly or not infectious. Additionally, infectious low-density $\mathrm{HCV}$ virions were rich in apoE, and levels of apoE and HCV RNA in infectious fractions were positively correlated. A short interfering RNA (siRNA)-mediated knockdown of apoE expression reduced apoE secretion and caused an apparent dose-dependent suppression of $\mathrm{HCV}$ virion production in the cells. However, the amount of HCV RNAcontaining particles was not significantly affected by an apoE overexpression indicating that the level of apoE expression is not a limiting factor for HCV replication. Chang et al. [49] suggested that apoE knockdown-associated reduction of HCV RNA-containing particles was not related to an inhibition of $\mathrm{HCV}$ release but was more likely due to the blockage of apoE dependent HCV virion assembly. Taken together these results demonstrate that in vitro apoE is required for the production of low-density HCV particles as well as for their infectivity. However, mechanisms of apoE genotype-specific effects on HCV life cycle remain uncertain [49]. Since HCV particles are supposed to enter target cells via LDL-R [57] and thus, compete with apoE containing lipoproteins for receptor binding [1], it was hypothesised that the already established decreased LDL-R expression in $\varepsilon 4$ vs. $\varepsilon 3$ carriers [58] could diminish hepatic HCV uptake and spread between hepatocytes [48].

In summary apoE seems to be involved in the HCV life cycle. Although the mechanisms are yet poorly understood, the apoE4 isoform appears to have a HCV-specific protective effect on liver disease with available data indicating that the outcome of chronic HCV infection is better among $\varepsilon 4$ carriers due to slower fibrosis progression. Limited evidence indicates that the $\varepsilon 4$ allele may also be associated with poor viral treatment response.

\section{HIV infection and HIV-associated dementia}

Infection with HIV and progression to the acquired immunodeficiency syndrome (AIDS) is a growing global health problem. At the end of 2007, the Joint United Nations Programme on HIV/AIDS estimated that 33.2 million people were living with HIV, 95\% of them in developing countries [61]. 


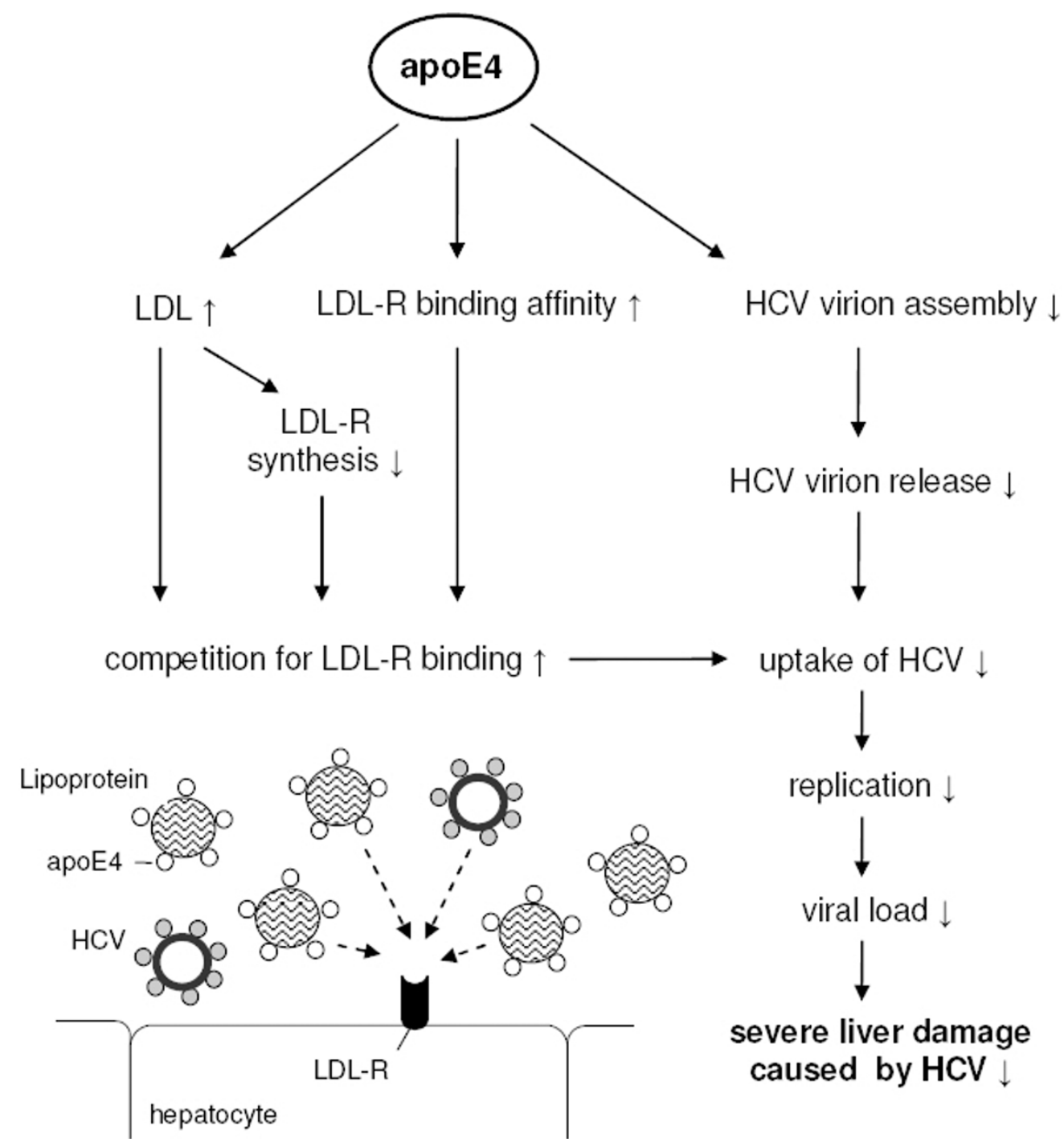

Figure 1 Potential mechanisms of the impact of apoE4 on viral treatment response, fibrosis progression in recurrent $\mathrm{HCV}$ infection as well as protection against HCV associated severe liver damage. LDL: low density lipoprotein, LDL-R: low density lipoprotein receptor, HCV: hepatitis $C$ virus

Target cells of HIV are macrophages and brain microglia, in particular $\mathrm{CD} 4^{+} \mathrm{T}$-lymphocyte cells [62]. These cells are infected by HSPG mediated virus attachment [63] followed by binding of HIV envelope glycoproteins to the CD4 receptor. The resulting conformational change allows the envelope glycoproteins to bind to one of the two possible co-receptors CCR5 and CXCR4 [62]. In preparation of cell entry, HIV fuses with the target cell membrane, which requires cholesterol in HIV particles and lipid rafts (membrane microdomains enriched in certain lipids, cholesterol and proteins) $[64,65]$. The infected cells synthesise HIV proteins including the HIV transactivator protein (Tat) that activates viral and cellular gene expression [66]. Newly assembled virus particles are transported to the cell surface and released by exocytotic fusion with the plasma membrane for further cell infection [67].

The acute phase of HIV infection is characterised by extensive and rapid loss of $\mathrm{CD}_{4}^{+}$cells due to apoptosis that persists into the chronic phase of infection. Plasma levels of $\mathrm{CD} 4^{+}$cells are partially reconstituted after the first infection period, but then decrease continuously. Counting $\mathrm{CD}^{+}$cells is therefore a key measure to assess progression of HIV disease [68]. Antiretroviral therapy is currently the best known way to protect mucosal tissue and to prevent microbial translocation and chronic activation of the immune system. It reduces the plasma levels of HIV RNA and induces a greater reconstitution of $\mathrm{CD}^{+}{ }^{+}$cells [68]. A low $\mathrm{CD} 4^{+}$cell count is an independent risk factor for HIV-associated 
dementia [69] which is developed by approximately onethird of HIV infected adults. HIV-associated dementia is accompanied by microglial cell activation, astrocytosis, decreased synaptic and dendritic density and selective neuronal loss [70]. Symptomatic parallels between HIVassociated dementia and AD have been previously reported [69,71]. HIV infection of microglia, neurons and astrocytes in associated with stimulation of tumor necrosis factor $\alpha$ (TNF- $\alpha$ ) and inducible nitric oxide synthase (iNOS) expression in the neighbouring uninfected cells [72], which have also been observed in AD [69]. In vitro, TNF- $\alpha$ substantially enhances the transcription of HIV in chronically infected mononuclear cells [73-75]. The pathogenesis of HIV and AIDS is therefore directly connected with the activation state of the host immune system [76].

Given that cholesterol is a crucial component of the HIV envelope and essential for viral entry and assembly $[64,77,78]$ and that apoE is essential for cholesterol transport [10], along with being a mediator of brain inflammatory process [79], it may be hypothesised that the apoE genotype influences HIV-induced effects on neurological functions. Table 3 summarises studies on the effect of apoE4 on HIV pathogenesis and related disorders in humans.

In a study by Corder et al. [69] HIV infected patients were evaluated every six months during a period of five years. Although non-significant, a tendency towards decreased $\mathrm{CD} 4^{+}$cell count was evident in $\varepsilon 4$ carriers. In addition, a highly significant difference of frequencies of neurological symptoms was evident with an incidence of $30 \%$ in $\varepsilon 4$ carriers and $15 \%$ in non- $\varepsilon 4$ carriers. Peripheral neuropathy was also more common among individuals carrying $\varepsilon 4$ [69].

An acceleration of the HIV disease course by apoE4 has also been observed in the Hawaii Aging with HIV Cohort. Those HIV patients who possessed at least one $\varepsilon 4$ allele tended to have a faster self-reported HIV progression with 8.3 compared to 10.5 years. However, $\mathrm{CD} 4^{+}$cell count as an indicator of disease progression as well as plasma HIV RNA and intracellular HIV DNA levels were not affected by apoE4 [71]. Further classification of the cohort revealed that the $\varepsilon 4$ allele was more frequent in the younger group $(<40$ years, $37 \%$ ), than in the older group ( $>50$ years, $23 \%$ ) indicating that $\varepsilon 4$ may influence survival. In contrast to the younger individuals, in the older cohort an apoE4 genotype was associated with an increased risk of HIVassociated dementia after controlling for age and diabetes status [80]. These findings highlight the possibility of an impact of age on the ability of apoE genotype to module the risk of developing HIV-associated dementia [71].

However further larger studies have failed to confirm this impact of apoE genotype on HIV-associated dementia prevalence [63,81]. Dunlop et al. [81] did not observe any differences in allele distribution among AIDS patients with clinical signs of dementia or histological signs of encephalitis relative to patients free of these clinical symptoms. The impact of a homozygous $\varepsilon 4 / \varepsilon 4$ genotype was not determinable due to the low presence among the study participants [81]. Consistent with the Dunlop findings Burt et al. [63] did not observe any significant impact of genotype on the risk of acquiring HIV infection and HIV-associated dementia. However there was some evidence to suggest that apoE genotype influenced the course of infection, with homozygosity for the $\varepsilon 4$ allele associated with an accelerated course of disease. The impact of $\varepsilon 4 / \varepsilon 4$ genotype on disease progression was not influenced by $\mathrm{CD} 4^{+}$cell count. In contrast, the effect of $\varepsilon 4 / \varepsilon 4$ genotype on the course of HIV was minimised after adjustment for the steady-state viral load, indicating that the extent of viral replication is affected by apoE genotype.

Furthermore, Burt et al. demonstrated in an in vitro model that the cell entry of HIV strains is apoE isoform

Table 3 Effects of apoE4 genotype on HIV course of disease and HIV-associated dementia in humans

\begin{tabular}{|c|c|c|c|}
\hline Reference & Subjects and profile & Parameter & Outcome \\
\hline $\begin{array}{l}\text { Corder et al. } 1998 \\
\text { [69] }\end{array}$ & 44 HIV infected patients & $\begin{array}{l}\text { - risk of HIV-associated dementia } \\
\text { - risk of peripheral neuropathy in HIV } \\
\text { infection }\end{array}$ & $\begin{array}{l}\varepsilon 4>\text { non- } \varepsilon 4 \\
\varepsilon 4>\text { non- } \varepsilon 4\end{array}$ \\
\hline $\begin{array}{l}\text { Dunlop et al. } 1997 \\
\text { [81] }\end{array}$ & $\begin{array}{l}132 \text { AIDS patients and postmortem samples of } \\
\text { hippocampus }\end{array}$ & $\begin{array}{l}\text { risk of HIV-associated dementia and } \\
\text { encephalitis }\end{array}$ & $\varepsilon 2=\varepsilon 3=\varepsilon 4$ \\
\hline $\begin{array}{l}\text { Burt et al. } 2008 \\
\text { [63] }\end{array}$ & $\begin{array}{l}\text { 1,267 HIV-positive patients and 1,132 healthy } \\
\text { controls }\end{array}$ & $\begin{array}{l}\text { - risk of acquiring HIV infection } \\
\text { - acceleration of HIV disease progression } \\
\text { - increase of steady-state viral load } \\
\text { - risk of HIV-associated dementia }\end{array}$ & $\begin{array}{l}\varepsilon 2=\varepsilon 3=\varepsilon 4 \\
\varepsilon 4 / \varepsilon 4>\varepsilon 3 / \text { non- } \varepsilon 3 \text { and } \varepsilon 3 / \varepsilon 3 \\
\varepsilon 4 / \varepsilon 4>\varepsilon 4 / \text { non- } \varepsilon 4>\text { non- } \varepsilon 4 / \\
\text { non- } \varepsilon 4 \\
\varepsilon 4=\text { non- } \varepsilon 4\end{array}$ \\
\hline $\begin{array}{l}\text { Valcour et al. } 2004 \\
\text { [80] }\end{array}$ & $\begin{array}{l}222 \text { HIV-positive patients of the Hawaii Aging with } \\
\text { HIV Cohort }\end{array}$ & $\begin{array}{l}\text { - } \varepsilon 4 \text { allele frequency } \\
\text { - risk of HIV-associated dementia }\end{array}$ & $\begin{array}{l}\text { younger cohort }>\text { older cohort } \\
\varepsilon 4>\text { non- } \varepsilon 4 \text { within the older } \\
\text { cohort }\end{array}$ \\
\hline
\end{tabular}


dependent with a significantly higher cell infection rate in the presence of apoE4 compared with apoE3, which may in part explain the higher infection rate in $\varepsilon 4$ carriers [63].

In summary, available evidence indicates that the $\varepsilon 4$ allele has detrimental effects on the course of HIV infections. It has been associated with higher steady-state viral load and faster disease progression due to accelerated virus entry in $\varepsilon 4$ carriers. However, $\mathrm{CD} 4^{+}$cell count does not appear to be significantly affected by the apoE genotype. The correlation between apoE4 and HIV-associated dementia is possibly age dependent, but remains controversial and needs to be clarified by further studies.

Possible mechanisms of the impact of apoE4 on HIV infection and HIV-associated dementia

Although the risk of acquiring HIV infection is independent of the apoE allelic variant, carriage of $\varepsilon 4$ is associated with an increased steady-state viral load and a faster progression of HIV disease. Furthermore, an increased cell entry of HIV in vitro strains was discovered in the presence of apoE4 compared to the presence of apoE3 [63].

One possible underlying mechanism may be an impact of apoE genotype on LDL-R and HSPG binding activities which would directly impact on cellular HIV particle uptake (figure 2). ApoE found on the virus' envelope may facilitate virus entry by targeting HIV virions to the LDL-R expressing cells [82]. ApoE4's modestly higher receptor binding affinity may promote virus contact to target cells and hence increases HIV cell entry and as a consequence disease progression.

Dobson et al. demonstrated in an in vitro experiment that short apoE fragments containing the heparin-binding domain, namely residues 142 to 147 , have antiviral activity against HIV infection. This effect possibly results from blockade of HIV attachment to HSPG (figure 2) [83]. The observation of lower HSPG mediated VLDL

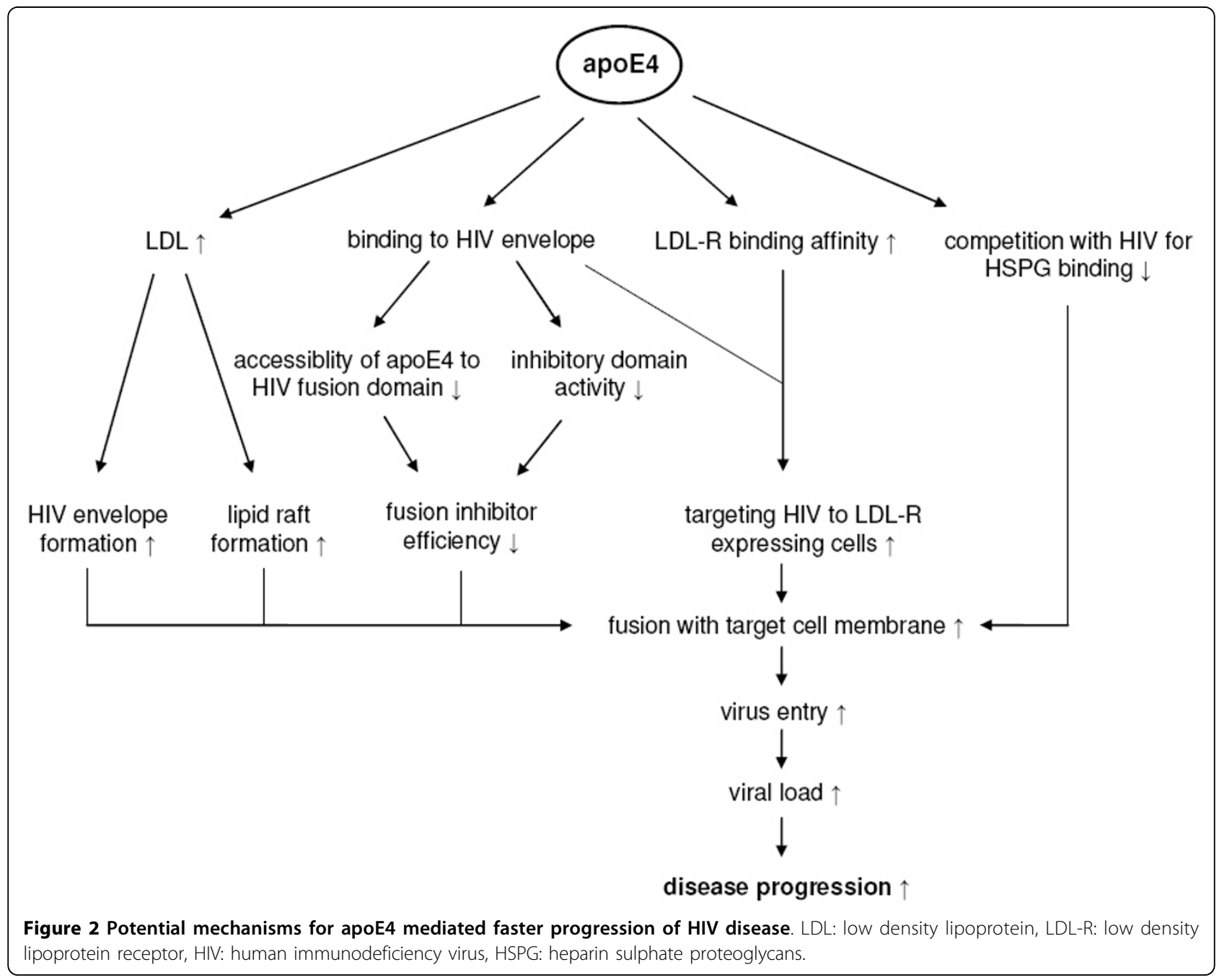


uptake of apoE4 versus apoE2 and apoE3 containing lipoproteins in a variety of cells cell lines [84] suggests that in apoE4 individuals lower competition is likely to be associated with accelerated HSPG mediated HIV cell entry.

In addition, the amphipathic helical domain of apolipoproteins shows homology with the viral fusogenic domains $[63,83,85]$ and therefore Burt et al. [63] proposed that the amphipathic helical domain of apoE may act as a HIV fusion inhibitor by binding to the HIV membrane protein gp41 and blocking either the formation or the function of the HIV N-terminal fusogenic domain. Based on the observation that apoE4, compared to apoE3, enhances HIV fusion and cell entry, apoE4 seems to be a less efficient fusion inhibitor [63]. The differential antiviral activity of apoE isoforms may be due to either these structural characteristics that make the amphipathic helical domain of apoE4 less accessible to HIV fusion domains or to isoform-specific changes in inhibitory domain activity [63] (figure 2).

Cholesterol is a crucial component of the HIV envelope as well as of cholesterol rich lipid rafts which are essential for both, HIV entry and release $[64,77,78]$. Consequently, depletion of cholesterol from either the cell membrane or the HIV envelope results in a loss of infectivity [64,77]. ApoE4 genotype is associated with higher LDL levels and might therefore support an accumulation of plasma membrane raft-associated cholesterol and an increase of lipid raft formation, resulting in an enhancement of HIV infection cycle including HIV fusion and cell entry as well as assembly of HIV virions and its release [63]. In addition, the increased LDL levels in $\varepsilon 4$ carriers may promote the formation of HIV envelopes and therewith of HIV virions, presumably resulting in higher viral load and faster disease progression as summarised in figure 2 .

The validity and relative importance of the above mentioned mechanisms proposed to underlie the impact of apoE genotype on HIV cell entry and viral load requires further investigation.

The neurotoxic protein Tat has been proposed to be involved in the development of HIV-associated dementia $[66,70]$. Tat is actively released mainly from HIV infected macrophages, astrocytes and microglia and is taken up by uninfected cells [66,86-90]. It is supposed to interact with neuronal membranes inducing oxidative stress. A higher Tat-induced oxidative damage was evident in wild-type relative to apoE-knockout mice attributed to a competition between apoE and Tat for LRP-R uptake [66]. In the presence of murine apoE, the contact time of Tat with cell membranes is prolonged, increasing the degree of Tat-induced oxidative damage. In cortical neurones Tat-induced toxicity was lower in presence of lipid-associated human apoE3 as compared to apoE4 indicating less oxidative damage in membrane lipids and proteins [66].

Figure 3 schematically summarises possible mechanisms underlying apoE genotype-HIV-associated dementia-interactions.

\section{Herpes simplex}

Herpes simplex is a neurotropic infectious disease caused by a herpes simplex virus (HSV) which is an enveloped double stranded DNA virus [91] classified into two subspecies. Herpes simplex virus type 1 (HSV1) contributes to the pathogenesis of numerous clinical conditions in humans with herpes labialis, also known as cold scores or fever blisters, being the symptom most often recognised [1], while herpes simplex virus type 2 (HSV-2) usually causes genital infections [92]. Seroprevalences of $\mathrm{HSV}-1$ and $\mathrm{HSV}-2$ infections increase with age. HSV-1 is spread more widely than HSV-2 [92] and one of the most commonly encountered pathogens with a prevalence of $40-50 \%$ among adolescents and 60-90\% among adult populations [93].

HSV-1 DNA is detectable in brain regions mainly affected in AD [94]. Though HSV-1 has been described as reducing overall synthesis of most host cell proteins, it has been shown to trigger cellular $\beta$-amyloid production and accumulation, which is a major hallmark of $\mathrm{AD}$ [95]. Interestingly, $\beta$-amyloid peptide and glycoprotein $B$ of HSV-1 viral envelopes show significant amino acid sequence homology [96].

There are few studies investigating a potential association between HSV-1 infection, apoE4 genotype and development of AD with inconsistent outcomes (summarised in table 4).

The susceptibility to HSV-1 infection was not affected by apoE genotype [97]. In an elderly cohort, apoE $\varepsilon 4$ allele frequency was found to be highest among HSV-1positive AD patients compared to HSV-1-negative AD patients and to non-AD patients indicating a several times higher AD risk for subjects carrying $\varepsilon 4$ allele with HSV-1 infection than for non- $\varepsilon 4$ carriers [98]. Thus, the HSV-1 infection alone shows no effect, but in combination with the apoE4 genotype the risk of $\mathrm{AD}$ increases apparently in the elderly [99]. Increasing age may facilitate viral entry into the CNS by declined immune or barrier function since HSV-1 was not detected in brains of younger people [98]. In addition to the increased susceptibility of the central nervous system the apoE4 genotype was also reported to increase the risk of HSV-1 induced cold scores in the peripheral nervous tissue [98].

In contrast in a prospective population based study of 512 non-demented elderly subjects a significant association between primary HSV-1 infection or reactivation (IgM-positive status) and development of AD was 


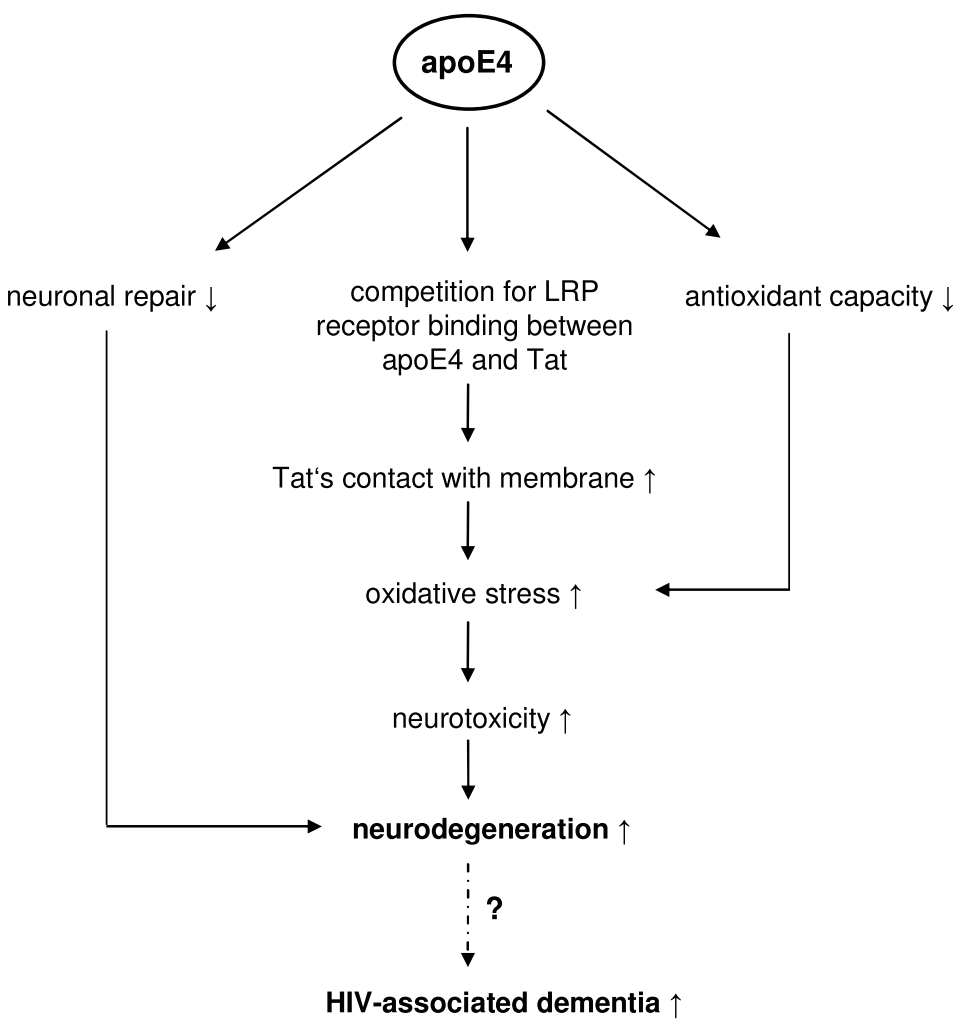

Figure 3 Possible mechanisms of the impact of apoE4 on increased neurodegeneration and HIV-associated dementia. Tat: transactivator protein, LRP: low density lipoprotein receptor-related protein, HIV: human immunodeficiency virus.

found. Over the period of 14 years 99 subjects developed dementia including 77 cases of AD. However, no interactions between the apoE genotype and IgM-positive status on the risk of $\mathrm{AD}$ could be observed, although the relatively small number of $\varepsilon 4$ carriers with HSV-1 infection has to be considered [100]. Nevertheless, in a previous study the combination of HSV-1 infection and apoE4 genotype did also not reveal any significant effect on the prevalence of AD [97].
Studies in transgenic apoE mice provide further evidence of an interaction between the apoE genotype and HSV-1 infection. Burgos et al. [101] analysed the involvement of different apoE isoforms in HSV-1 access to the CNS during the acute phase of infection. Thus, 14week-old female apoE3 and apoE4 transgenic mice were inoculated with HSV-1 and the infection status of several tissues was analysed six days after inoculation. ApoE isoform dependent differences in the viral load in the CNS and certain brain regions were observed.

Table 4 Effects of apoE4 genotype on herpes simplex virus (HSV)-1 infection and outcome in humans

\begin{tabular}{|c|c|c|c|}
\hline Reference & Subjects and profile & Parameter & Outcome \\
\hline \multirow[t]{2}{*}{$\begin{array}{l}\text { Itzhaki et al. } \\
1997 \text { [98] }\end{array}$} & $\begin{array}{l}46 \text { Caucasian AD patients and } 44 \text { Caucasian } \\
\text { non-AD elderly controls }\end{array}$ & risk of $A D$ & highest in $\varepsilon 4$ carriers positive for HSV-1 \\
\hline & $\begin{array}{l}40 \text { Caucasian cold-score sufferers and } 33 \\
\text { age-matched Caucasian healthy controls }\end{array}$ & $\begin{array}{l}\text { risk of HSV-1-induced cold- } \\
\text { scores }\end{array}$ & $\varepsilon 4>$ non- $\varepsilon 4$ \\
\hline $\begin{array}{l}\text { Itabashi et } \\
\text { al. } 1997 \text { [99] }\end{array}$ & $\begin{array}{l}46 \text { elderly } A D \text { patients and } 23 \text { age-matched } \\
\text { controls without confirmed neuropsychiatric } \\
\text { disease }\end{array}$ & HSV and risk of $A D$ & $\begin{array}{l}\text { latent HSV infection alone is not an independent risk } \\
\text { factor for } A D \text {, the combination of } \varepsilon 4 \text { and HSV infection } \\
\text { increases the risk }\end{array}$ \\
\hline $\begin{array}{l}\text { Beffert et al. } \\
1998 \text { [97] }\end{array}$ & $\begin{array}{l}73 \text { elderly AD patients and } 33 \text { non-AD } \\
\text { controls }\end{array}$ & $\begin{array}{l}\text { - susceptibility to HSV-1 } \\
\text { infection in brain } \\
\text { - risk of } A D\end{array}$ & $\begin{array}{l}\varepsilon 4=\text { non- } \varepsilon 4 \\
\text { no effect of HSV-1 and } \varepsilon 4 \text { combined }\end{array}$ \\
\hline $\begin{array}{l}\text { Letenneur et } \\
\text { al. } 2008 \\
{[100]}\end{array}$ & $\begin{array}{l}512 \text { French individuals in a population } \\
\text { based cohort study }\end{array}$ & $\begin{array}{l}\text { apoE genotype and HSV } \\
\text { immunoglobulin status as risk } \\
\text { factors for } A D\end{array}$ & $\begin{array}{l}\text { no interactions between apoE status and HSV } \\
\text { immunoglobulin status on risk of AD }\end{array}$ \\
\hline
\end{tabular}

HSV: herpes simplex virus, AD: Alzheimer's disease, CNS: central nervous system 
ApoE4 transgenic mice had significantly higher HSV-1 levels in the spinal cord and in all regions of the brain. HSV-1 levels in the cortex, cerebellum and ventricles of apoE3 transgenic mice were undetectable, while apoE4 transgenic mice showed significantly higher levels of HSV-1 in these brain regions. However, no significant differences were detected in the blood and the adrenal glands. These data show that apoE4 facilitates migration of HSV-1 from the adrenal gland to the brain ten times more efficiently than apoE3 [101].

In a further study, the influence of the apoE profile on levels of latent HSV-1 DNA was investigated in the same rodent model [94]. Since HSV-1 is present in a latent state four weeks after inoculation, viral DNA concentration was determined five weeks after infection, when latency was assured. The highest virus loads were found in the nervous system, including spinal cord, brain and trigeminal ganglia, and in the blood possibly derived from the trigeminal ganglia. Therefore, it has been suggested that a high viral load is accompanied with establishment of HSV-1 latency in the respective tissues. Wild-type mice showed significantly higher concentrations of HSV-1 than apoEknockout mice in the nervous tissue, adrenal glands and ovaries but similar concentrations in the blood. In comparison to apoE3 mice, apoE4 mice had higher levels of latent HSV-1 DNA, except for the adrenal glands and the blood. In the apoE4 mice HSV-1 was detected in all brain regions analysed, while in apoE3 mice HSV-1 was only detectable in the midbrain. Latent HSV-1 DNA levels in the nervous system were twelve times higher in the presence of apoE4 compared to apoE3 [94]. Burgos et al. [94] suggested that apoE4 may increase the risk of developing AD by increasing latent HSV-1 viral load in the nervous system. The ability to cause damage may depend on the exact location, the immune status of the host, and the amount of virus (in which apoE genotype status could play an important role) [94].

In conclusion, current literature indicates that apoE4 intensifies the susceptibility for HSV-1 related herpes labialis as well as the neuroinvasiveness of HSV-1 compared to other apoE variants and that the combination of apoE4 and HSV-1 may lead to a higher risk of AD, than either factor in isolation. However inconsistencies exist in the literature, which is likely to be in large part due to the lack of the statistical power of the human studies conducted to date.

\section{Possible mechanisms of the impact of apoE4 on herpes simplex (Figure 4)}

Similar to HCV and HIV, HSV competes with apoE for receptor binding [1]. In addition $\mathrm{HSV}$ attachment to the target cells is facilitated by HSPG located on the cell's surface [102]. Therefore differences in apoE-HSPG associations are also likely to impact on the cellular HSV uptake as proposed by Itzhaki and Wozniak [1]. Furthermore, lipid rafts are involved in HSV entry as well [65]. As discussed for HIV, the higher levels of LDL present in $\varepsilon 4$ carriers possibly support an accumulation of cholesterol in these specialised membrane domains and increases their formation [63]. This would enhance virus entry and therewith the chance for HSV to establish latency.

HSV-1 infection of the murine nervous system is associated with up-regulated iNOS expression as well as raised levels of pro-inflammatory cytokines [103,104] which undoubtedly play a central role in the neuronal injury associated with the viral infection. Given the observation of increased oxidative stress, inflammatory cytokine production and nitric oxide production associated with an apoE4 genotype [8,105-107] and the less efficient neuronal repair described in E4 carriers [69], this considerable overlap between the pathological effects of an apoE4 genotype and the neuronal impact of the HSV provides a likely mechanism to explain the observation of increased AD risk in E4 carriers associated with HSV infection.

\section{Conclusion}

This review provides an overview of the so far available data on the involvement of the apoE genotype in the pathogenesis of specific virus diseases. It is conceivable that due to its beneficial effects in certain harmful infectious diseases, as demonstrated for hepatitis $C$, the $\varepsilon 4$ allele may not have been eliminated by evolutionary selection. In such a way there exists a geographical north-south gradient in Italy with a higher number of $\mathrm{HCV}$ infections in the south of Italy [108] parallel to the inverse geographical gradient in apoE4 genotype frequency being lowest in southern Italy [36]. However, substantial studies are needed to correlate geographical differences and ethnic origins with the incidence of these virus infections.

The mechanisms of HCV, HIV and HSV infection bear resemblance to each other, since all three viruses compete with apoE for cell attachment and receptor binding. Therefore it would be interesting to investigate whether other types of viruses share the same mechanism and whether their cell entry is affected by the apoE genotype. This could contribute to our understanding of the apparent paradox that apoE4 competes efficiently with $\mathrm{HCV}$ for receptor binding but is less efficient in inhibiting the binding of HIV and HSV to the receptors.

Since the detailed mechanisms of the impact of apoE4 on the virus cell entry, the infection cycle and the virus-induced disorders are not completely understood, further experimental and clinical studies are needed. 


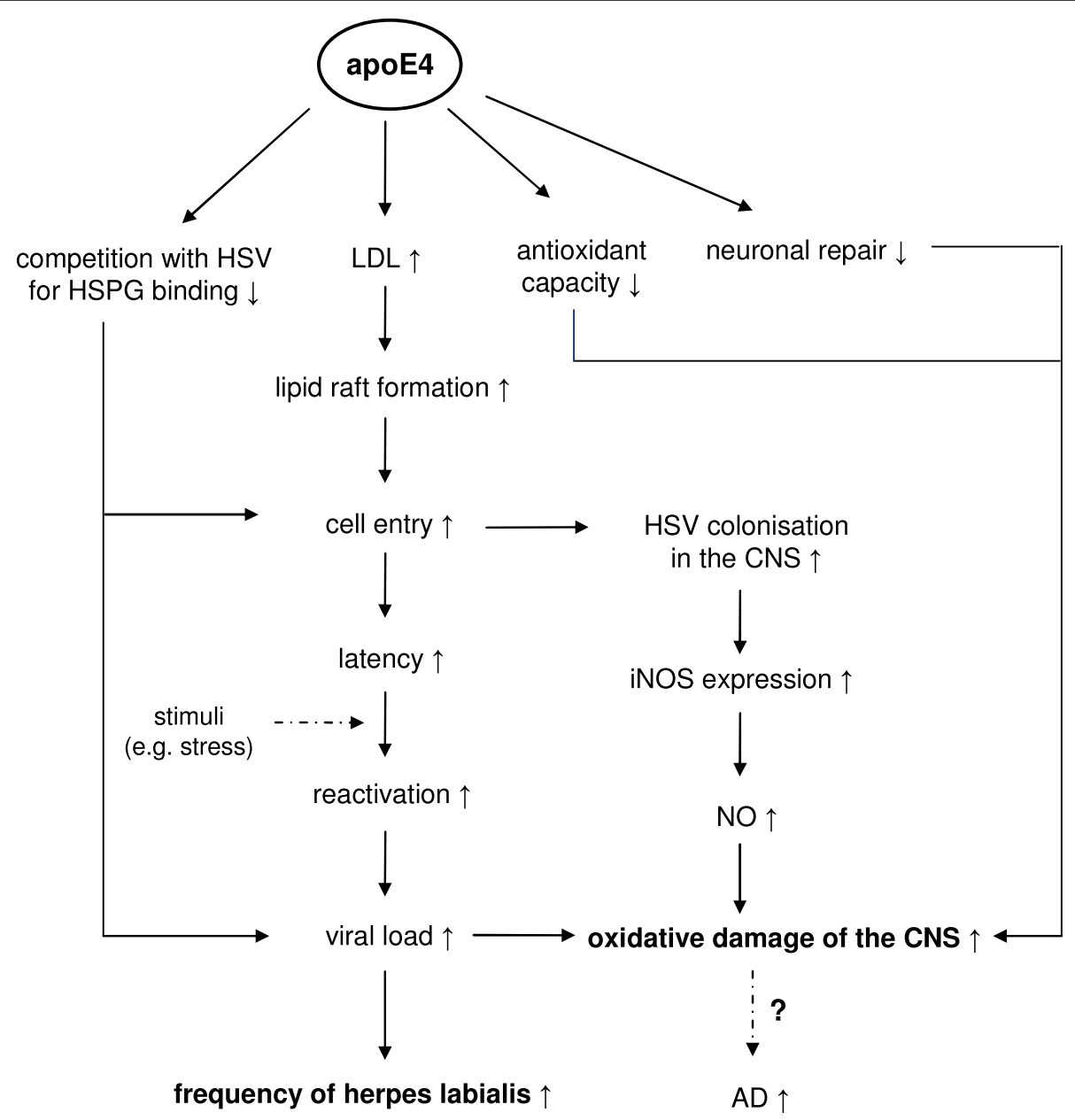

Figure 4 Possible mechanisms of the adverse effects of apoE4 on the outcome of herpes labialis and the increased HSV-induced oxidative damage in the CNS that possibly increases the susceptibility to AD. HSV: herpes simplex virus, HSPG: heparin sulphate proteoglycans, LDL: low density lipoprotein, iNOS: inducible nitric oxide synthase, NO: nitric oxide, CNS: central nervous system, AD: Alzheimer's disease.

The knowledge of the mechanisms by which apoE may influence the pathogenesis of infectious virus diseases may open up novel strategies to develop personalised antiviral treatments depending on the individual's apoE genotype.

\section{Author details}

${ }^{1}$ Institute of Human Nutrition and Food Science, Christian-AlbrechtsUniversity, Hermann-Rodewald-Strasse 6, 24098 Kiel, Germany. ${ }^{2}$ Department of Physiology, Faculty of Medical and Health Sciences, The University of Auckland, Private Bag 92019, Mail Centre, Auckland 1142, New Zealand. ${ }^{3}$ Institute of Clinical Molecular Biology, Christian-Albrechts-University, Schittenhelmstrasse 12, 24105 Kiel, Germany.

\section{Authors' contributions}

IK, AMM, PH, AN and GR wrote the manuscript. All authors contributed to the revision of the manuscript. IK prepared the figures of the manuscript.

\section{Competing interests}

The authors declare that they have no competing interests.
Received: 17 December 2009

Accepted: 28 January 2010 Published: 28 January 2010

\section{References}

1. Itzhaki RF, Wozniak MA: Herpes simplex virus type 1, apolipoprotein E, and cholesterol: a dangerous liaison in Alzheimer's disease and other disorders. Prog Lipid Res 2006, 45(1):73-90.

2. Mahley RW, Rall SC Jr: Apolipoprotein E: far more than a lipid transport protein. Annu Rev Genomics Hum Genet 2000, 1:507-537.

3. Rall SC Jr, Weisgraber KH, Mahley RW: Human apolipoprotein E. The complete amino acid sequence. J Biol Chem 1982, 257(8):4171-4178.

4. Basu SK, Ho YK, Brown MS, Bilheimer DW, Anderson RG, Goldstein JL: Biochemical and genetic studies of the apoprotein E secreted by mouse macrophages and human monocytes. J Biol Chem 1982, 257(16):9788-9795.

5. Newman TC, Dawson PA, Rudel LL, Williams DL: Quantitation of apolipoprotein E mRNA in the liver and peripheral tissues of nonhuman primates. J Biol Chem 1985, 260(4):2452-2457.

6. Eichner JE, Dunn ST, Perveen G, Thompson DM, Stewart KE, Stroehla BC Apolipoprotein E polymorphism and cardiovascular disease: a HuGE review. Am J Epidemiol 2002, 155(6):487-495. 
7. Minihane AM, Jofre-Monseny L, Olano-Martin E, Rimbach G: ApoE genotype, cardiovascular risk and responsiveness to dietary fat manipulation. Proc Nutr Soc 2007, 66(2):183-197.

8. Jofre-Monseny L, Minihane AM, Rimbach G: Impact of apoE genotype on oxidative stress, inflammation and disease risk. Mol Nutr Food Res 2008, 52(1):131-145.

9. de Chaves EP, Narayanaswami V: Apolipoprotein E and cholesterol in aging and disease in the brain. Future Lipidol 2008, 3(5):505-530.

10. Mahley RW, Innerarity TL, Rall SC Jr, Weisgraber KH: Plasma lipoproteins: apolipoprotein structure and function. J Lipid Res 1984, 25(12):1277-1294

11. Strickland DK, Gonias SL, Argraves WS: Diverse roles for the LDL receptor family. Trends Endocrinol Metab 2002, 13(2):66-74.

12. Mahley RW, Ji ZS: Remnant lipoprotein metabolism: key pathways involving cell-surface heparan sulfate proteoglycans and apolipoprotein E. J Lipid Res 1999, 40(1):1-16

13. Liu Y, Jones M, Hingtgen CM, Bu G, Laribee N, Tanzi RE, Moir RD, Nath A, He JJ: Uptake of HIV-1 tat protein mediated by low-density lipoprotein receptor-related protein disrupts the neuronal metabolic balance of the receptor ligands. Nat Med 2000, 6(12):1380-1387.

14. Myklebost O, Rogne S, Olaisen B, Gedde-Dahl T Jr, Prydz H: The locus for apolipoprotein CII is closely linked to the apolipoprotein E locus on chromosome 19 in man. Hum Genet 1984, 67(3):309-312.

15. Scott J, Knott TJ, Shaw DJ, Brook JD: Localization of genes encoding apolipoproteins $\mathrm{Cl}, \mathrm{Cll}$, and $\mathrm{E}$ to the p13-Cen region of human chromosome 19. Hum Genet 1985, 71(2):144-146.

16. National Center for Biotechnology Information, Database Single Nucleotide Polymorphism. http://www.ncbi.nlm.nih.gov/snp?term=apoE.

17. Weisgraber KH, Rall SC Jr, Mahley RW: Human E apoprotein heterogeneity. Cysteine-arginine interchanges in the amino acid sequence of the apo-E isoforms. J Biol Chem 1981, 256(17):9077-9083.

18. Zannis VI, Breslow JL, Utermann G, Mahley RW, Weisgraber KH, Havel RJ, Goldstein JL, Brown MS, Schonfeld G, Hazzard WR, et al: Proposed nomenclature of apoE isoproteins, apoE genotypes, and phenotypes. J Lipid Res 1982, 23(6):911-914.

19. Ordovas JM, Litwack-Klein L, Wilson PW, Schaefer MM, Schaefer EJ: Apolipoprotein $\mathrm{E}$ isoform phenotyping methodology and population frequency with identification of apoE1 and apoE5 isoforms. J Lipid Res 1987, 28(4):371-380.

20. Siest G, Pillot T, Regis-Bailly A, Leininger-Muller B, Steinmetz J, Galteau MM, Visvikis S: Apolipoprotein E: an important gene and protein to follow in laboratory medicine. Clin Chem 1995, 41(8 Pt 1):1068-1086.

21. Nebel A, Croucher PJ, Stiegeler R, Nikolaus S, Krawczak M, Schreiber S: No association between microsomal triglyceride transfer protein (MTP) haplotype and longevity in humans. Proceedings of the National Academy of Sciences of the United States of America 2005, 102(22):7906-7909.

22. Panza F, D'Introno A, Colacicco AM, Capurso C, Capurso S, Kehoe PG, Capurso A, Solfrizzi V: Vascular genetic factors and human longevity. Mechanisms of ageing and development 2004, 125(3):169-178.

23. Corder EH, Saunders AM, Strittmatter WJ, Schmechel DE, Gaskell PC, Small GW, Roses AD, Haines JL, Pericak-Vance MA: Gene dose of apolipoprotein E type 4 allele and the risk of Alzheimer's disease in late onset families. Science (New York, NY) 1993, 261(5123):921-923.

24. Bennet AM, Di Angelantonio E, Ye Z, Wensley F, Dahlin A, Ahlbom A, Keavney B, Collins R, Wiman B, de Faire U, et al: Association of apolipoprotein $\mathrm{E}$ genotypes with lipid levels and coronary risk. Jama 2007, 298(11):1300-1311.

25. Rimbach G, Minihane AM: Nutrigenetics and personalised nutrition: how far have we progressed and are we likely to get there?. Proc Nutr Soc 2009, 68(2):162-172.

26. Song Y, Stampfer MJ, Liu S: Meta-analysis: apolipoprotein E genotypes and risk for coronary heart disease. Annals of internal medicine 2004, 141(2):137-147.

27. Bertram L, McQueen MB, Mullin K, Blacker D, Tanzi RE: Systematic metaanalyses of Alzheimer disease genetic association studies: the AlzGene database. Nature genetics 2007, 39(1):17-23.

28. Farrer LA, Cupples LA, Haines JL, Hyman B, Kukull WA, Mayeux R, Myers RH, Pericak-Vance MA, Risch N, van Duijn CM: Effects of age, sex, and ethnicity on the association between apolipoprotein $\mathrm{E}$ genotype and Alzheimer disease. A meta-analysis. APOE and Alzheimer Disease Meta Analysis Consortium. Jama 1997, 278(16):1349-1356.
29. Mahley RW: Apolipoprotein E: cholesterol transport protein with expanding role in cell biology. Science (New York, NY) 1988, 240(4852):622-630.

30. Kelly ME, Clay MA, Mistry MJ, Hsieh-Li HM, Harmony JA: Apolipoprotein E inhibition of proliferation of mitogen-activated T lymphocytes: production of interleukin 2 with reduced biological activity. Cell Immunol 1994, 159(2):124-139.

31. Majewicz J, Rimbach G, Proteggente AR, Lodge JK, Kraemer K, Minihane AM: Dietary vitamin C down-regulates inflammatory gene expression in apoE4 smokers. Biochem Biophys Res Commun 2005, 338(2):951-955.

32. Jofre-Monseny L, Loboda A, Wagner AE, Huebbe P, Boesch-Saadatmandi C, Jozkowicz A, Minihane AM, Dulak J, Rimbach G: Effects of apoE genotype on macrophage inflammation and heme oxygenase-1 expression. Biochem Biophys Res Commun 2007, 357(1):319-324.

33. Boesch-Saadatmandi C, Wolffram S, Minihane AM, Rimbach G: Effect of apoE genotype and dietary quercetin on blood lipids and TNF-alpha levels in apoE3 and apoE4 targeted gene replacement mice. Br J Nutr 2009, 101(10):1440-1443.

34. Gerdes LU, Gerdes C, Hansen PS, Klausen IC, Faergeman O, Dyerberg J: The apolipoprotein E polymorphism in Greenland Inuit in its global perspective. Hum Genet 1996, 98(5):546-550.

35. Lehtimaki T, Moilanen T, Viikari J, Akerblom HK, Ehnholm C, Ronnemaa T, Marniemi J, Dahlen G, Nikkari T: Apolipoprotein E phenotypes in Finnish youths: a cross-sectional and 6-year follow-up study. J Lipid Res 1990, 31(3):487-495.

36. Corbo RM, Scacchi R, Mureddu L, Mulas G, Alfano G: Apolipoprotein E polymorphism in Italy investigated in native plasma by a simple polyacrylamide gel isoelectric focusing technique. Comparison with frequency data of other European populations. Ann Hum Genet 1995, 59(Pt 2):197-209.

37. Schiele F, De Bacquer D, Vincent-Viry M, Beisiegel U, Ehnholm C, Evans A, Kafatos A, Martins MC, Sans S, Sass C, et al: Apolipoprotein E serum concentration and polymorphism in six European countries: the ApoEurope Project. Atherosclerosis 2000, 152(2):475-488.

38. Gerdes LU: The common polymorphism of apolipoprotein E: geographical aspects and new pathophysiological relations. Clin Chem Lab Med 2003, 41(5):628-631.

39. Fabris C, Toniutto P, Bitetto D, Minisini R, Smirne C, Caldato M, Pirisi M: Low fibrosis progression of recurrent hepatitis $C$ in apolipoprotein $E$ epsilon4 carriers: relationship with the blood lipid profile. Liver Int 2005, 25(6):1128-1135

40. Bednarska-Makaruk M, Broda G, Kurjata P, Rodo M, Roszczynko M, Rywik S, Wehr H: Apolipoprotein E genotype, lipid levels and coronary heart disease in a Polish population group. Eur J Epidemiol 2001, 17(8):789-792.

41. Assmann G, Schmitz G, Menzel HJ, Schulte H: Apolipoprotein E polymorphism and hyperlipidemia. Clin Chem 1984, 30(5):641-643.

42. Schoofs MW, Klift van der M, Hofman A, van Duijn CM, Stricker BH, Pols HA, Uitterlinden AG: ApoE gene polymorphisms, BMD, and fracture risk in elderly men and women: the Rotterdam study. I Bone Miner Res 2004, 19(9):1490-1496.

43. Sandholzer C, Delport R, Vermaak H, Utermann G: High frequency of the apo epsilon 4 allele in Khoi San from South Africa. Hum Genet 1995, 95(1):46-48.

44. Yang JG, Poropat RA, Brooks WS, Broe GA, Nicholson GA: Apolipoprotein E genotyping in Alzheimer's disease in an Australian sample. Aust $N Z J$ Med 1996, 26(5):658-661.

45. Kamboh MI, Serjeantson SW, Ferrell RE: Genetic studies of human apolipoproteins. XVIII. Apolipoprotein polymorphisms in Australian Aborigines. Hum Biol 1991, 63(2):179-186.

46. Aceves D, Ruiz B, Nuno P, Roman S, Zepeda E, Panduro A: Heterogeneity of apolipoprotein E polymorphism in different Mexican populations. Hum Biol 2006, 78(1):65-75

47. Poynard T, Yuen MF, Ratziu V, Lai CL: Viral hepatitis C. Lancet 2003, 362(9401):2095-2100.

48. Wozniak MA, Itzhaki RF, Faragher EB, James MW, Ryder SD, Irving WL: Apolipoprotein E-epsilon 4 protects against severe liver disease caused by hepatitis C virus. Hepatology 2002, 36(2):456-463.

49. Chang KS, Jiang J, Cai Z, Luo G: Human apolipoprotein e is required for infectivity and production of hepatitis C virus in cell culture. J Virol 2007, 81(24):13783-13793. 
50. Seeff LB, Hoofnagle JH: National Institutes of Health Consensus Development Conference: management of hepatitis C: 2002. Hepatology (Baltimore, Md) 2002, 36(5 Suppl 1):S1-2.

51. Berenguer M, Lopez-Labrador FX, Wright TL: Hepatitis $C$ and liver transplantation. J Hepatol 2001, 35(5):666-678.

52. Sud A, Hui JM, Farrell GC, Bandara P, Kench JG, Fung C, Lin R, Samarasinghe D, Liddle C, McCaughan GW, et al: Improved prediction of fibrosis in chronic hepatitis $C$ using measures of insulin resistance in a probability index. Hepatology 2004, 39(5):1239-1247.

53. Price DA, Bassendine MF, Norris SM, Golding C, Toms GL, Schmid ML, Morris CM, Burt AD, Donaldson PT: Apolipoprotein epsilon3 allele is associated with persistent hepatitis C virus infection. Gut 2006, 55(5):715-718.

54. Serfaty L, Andreani T, Giral P, Carbonell N, Chazouilleres O, Poupon R: Hepatitis $C$ virus induced hypobetalipoproteinemia: a possible mechanism for steatosis in chronic hepatitis C. J Hepatol 2001, 34(3):428-434.

55. Watson JP, Bevitt DJ, Spickett GP, Toms GL, Bassendine MF: Hepatitis C virus density heterogeneity and viral titre in acute and chronic infection: a comparison of immunodeficient and immunocompetent patients. Journal of hepatology 1996, 25(5):599-607.

56. Barth H, Schafer C, Adah MI, Zhang F, Linhardt RJ, Toyoda H, KinoshitaToyoda A, Toida T, Van Kuppevelt TH, Depla E, et al: Cellular binding of hepatitis $C$ virus envelope glycoprotein $E 2$ requires cell surface heparan sulfate. J Biol Chem 2003, 278(42):41003-41012.

57. Agnello V, Abel G, Elfahal M, Knight GB, Zhang QX: Hepatitis C virus and other flaviviridae viruses enter cells via low density lipoprotein receptor. Proc Natl Acad Sci USA 1999, 96(22):12766-12771.

58. Marz W, Scharnagl H, Hoffmann MM, Boehm BO, Winkelmann BR: The apolipoprotein E polymorphism is associated with circulating C-reactive protein (the Ludwigshafen risk and cardiovascular health study). Eur Heart J 2004, 25(23):2109-2119.

59. Mueller T, Gessner R, Sarrazin C, Halangk J, Wiedenmann B, Berg T: Protektiver Effekt des Apolipoprotein E4 Allels bei Hepatitis C Virus (HCV) Infektion. Z Gastroenterol 2007, 45:851.

60. Mueller T, Gessner R, Sarrazin C, Graf C, Halangk J, Witt H, Kottgen $E_{1}$ Wiedenmann B, Berg T: Apolipoprotein E4 allele is associated with poor treatment response in hepatitis $\mathrm{C}$ virus ( $\mathrm{HCV}$ ) genotype 1. Hepatology 2003, 38(6):1592, author reply 1592-1593.

61. AIDS epidemic update. http://data.unaids.org/pub/EPISlides/2007/ 2007_epiupdate_en.pdf.

62. Milush JM, Reeves JD, Gordon SN, Zhou D, Muthukumar A, Kosub DA, Chacko E, Giavedoni LD, Ibegbu CC, Cole KS, et al: Virally induced CD4+ T cell depletion is not sufficient to induce AIDS in a natural host. $J$ Immunol 2007, 179(5):3047-3056.

63. Burt TD, Agan BK, Marconi VC, He W, Kulkarni H, Mold JE, Cavrois M, Huang Y, Mahley RW, Dolan MJ, et al: Apolipoprotein (apo) E4 enhances HIV-1 cell entry in vitro, and the APOE epsilon4/epsilon4 genotype accelerates HIV disease progression. Proc Natl Acad Sci USA 2008, 105(25):8718-8723.

64. Liao Z, Graham DR, Hildreth JE: Lipid rafts and HIV pathogenesis: virionassociated cholesterol is required for fusion and infection of susceptible cells. AIDS Res Hum Retroviruses 2003, 19(8):675-687.

65. Bender FC, Whitbeck JC, Ponce de Leon M, Lou H, Eisenberg RJ, Cohen GH: Specific association of glycoprotein $B$ with lipid rafts during herpes simplex virus entry. J Virol 2003, 77(17):9542-9552.

66. Pocernich CB, Sultana R, Hone E, Turchan J, Martins RN, Calabrese V, Nath A, Butterfield DA: Effects of apolipoprotein $E$ on the human immunodeficiency virus protein Tat in neuronal cultures and synaptosomes. J Neurosci Res 2004, 77(4):532-539.

67. Pelchen-Matthews A, Kramer B, Marsh M: Infectious HIV-1 assembles in late endosomes in primary macrophages. J Cell Biol 2003, 162(3):443-455

68. Douek D: HIV disease progression: immune activation, microbes, and a leaky gut. Top HIV Med 2007, 15(4):114-117.

69. Corder EH, Robertson K, Lannfelt L, Bogdanovic N, Eggertsen G, Wilkins J, Hall C: HIV-infected subjects with the E4 allele for APOE have excess dementia and peripheral neuropathy. Nat Med 1998, 4(10):1182-1184.

70. Pocernich CB, Poon HF, Boyd-Kimball D, Lynn BC, Nath A, Klein JB, Butterfield DA: Proteomic analysis of oxidatively modified proteins induced by the mitochondrial toxin 3-nitropropionic acid in human astrocytes expressing the HIV protein tat. Brain Res Mol Brain Res 2005 133(2):299-306.

71. Valcour V, Shiramizu B, Shikuma C: Frequency of apolipoprotein E4 among older compared with younger HIV patients: support for detrimental effect of E4 on survival. Proc Natl Acad Sci USA 2008, 105(41):E66.

72. Nuovo GJ, Alfieri ML: AIDS dementia is associated with massive, activated HIV-1 infection and concomitant expression of several cytokines. $\mathrm{Mol}$ Med 1996, 2(3):358-366.

73. Okamoto T, Matsuyama T, Mori S, Hamamoto $Y$, Kobayashi N, Yamamoto N, Josephs SF, Wong-Staal F, Shimotohno K: Augmentation of human immunodeficiency virus type 1 gene expression by tumor necrosis factor alpha. AIDS research and human retroviruses 1989, 5(2):131-138.

74. Folks TM, Clouse KA, Justement J, Rabson A, Duh E, Kehrl JH, Fauci AS Tumor necrosis factor alpha induces expression of human immunodeficiency virus in a chronically infected T-cell clone. Proceedings of the National Academy of Sciences of the United States of America 1989, 86(7):2365-2368.

75. Clouse KA, Powell D, Washington I, Poli G, Strebel K, Farrar W, Barstad P, Kovacs J, Fauci AS, Folks TM: Monokine regulation of human immunodeficiency virus-1 expression in a chronically infected human $T$ cell clone. J Immunol 1989, 142(2):431-438.

76. Lawn SD, Butera ST, Folks TM: Contribution of immune activation to the pathogenesis and transmission of human immunodeficiency virus type 1 infection. Clin Microbiol Rev 2001, 14(4):753-777.

77. Manes S, del Real G, Lacalle RA, Lucas P, Gomez-Mouton C, SanchezPalomino S, Delgado R, Alcami J, Mira E, Martinez AC: Membrane raft microdomains mediate lateral assemblies required for HIV-1 infection. EMBO Rep 2000, 1(2):190-196.

78. Campbell SM, Crowe SM, Mak J: Lipid rafts and HIV-1: from viral entry to assembly of progeny virions. J Clin Virol 2001, 22(3):217-227.

79. Ophir G, Amariglio N, Jacob-Hirsch J, Elkon R, Rechavi G, Michaelson DM: Apolipoprotein E4 enhances brain inflammation by modulation of the NF-kappaB signaling cascade. Neurobiol Dis 2005, 20(3):709-718.

80. Valcour V, Shikuma C, Shiramizu B, Watters M, Poff P, Selnes OA, Grove J, Liu Y, Abdul-Majid KB, Gartner S, et al: Age, apolipoprotein E4, and the risk of HIV dementia: the Hawaii Aging with HIV Cohort. J Neuroimmunol 2004, 157(1-2):197-202

81. Dunlop O, Goplen AK, Liestol K, Myrvang B, Rootwelt H, Christophersen B, Kvittingen EA, Maehlen J: HIV dementia and apolipoprotein E. Acta Neurol Scand 1997, 95(5):315-318.

82. Chertova E, Chertov O, Coren LV, Roser JD, Trubey CM, Bess JW Jr, Sowder RC, Barsov E, Hood BL, Fisher RJ, et al: Proteomic and biochemical analysis of purified human immunodeficiency virus type 1 produced from infected monocyte-derived macrophages. J Virol 2006, 80(18):9039-9052.

83. Dobson CB, Sales SD, Hoggard P, Wozniak MA, Crutcher KA: The receptorbinding region of human apolipoprotein $E$ has direct anti-infective activity. J Infect Dis 2006, 193(3):442-450.

84. Ji ZS, Pitas RE, Mahley RW: Differential cellular accumulation/retention of apolipoprotein E mediated by cell surface heparan sulfate proteoglycans. Apolipoproteins E3 and E2 greater than e4. The Journal of biological chemistry 1998, 273(22):13452-13460.

85. Owens BJ, Anantharamaiah GM, Kahlon JB, Srinivas RV, Compans RW, Segrest JP: Apolipoprotein A-I and its amphipathic helix peptide analogues inhibit human immunodeficiency virus-induced syncytium formation. The Journal of clinical investigation 1990, 86(4):1142-1150.

86. Sabatier JM, Vives E, Mabrouk K, Benjouad A, Rochat H, Duval A, Hue B, Bahraoui E: Evidence for neurotoxic activity of tat from human immunodeficiency virus type 1. Journal of virology 1991, 65(2):961-967.

87. Chauhan A, Turchan J, Pocernich C, Bruce-Keller A, Roth S, Butterfield DA, Major EO, Nath A: Intracellular human immunodeficiency virus Tat expression in astrocytes promotes astrocyte survival but induces potent neurotoxicity at distant sites via axonal transport. The Journal of biological chemistry 2003, 278(15):13512-13519.

88. Chang HC, Samaniego F, Nair BC, Buonaguro L, Ensoli B: HIV-1 Tat protein exits from cells via a leaderless secretory pathway and binds to extracellular matrix-associated heparan sulfate proteoglycans through its basic region. Aids 1997, 11(12):1421-1431.

89. Ma M, Nath A: Molecular determinants for cellular uptake of Tat protein of human immunodeficiency virus type 1 in brain cells. Journal of virology 1997, 71(3):2495-2499. 
90. Ensoli B, Buonaguro L, Barillari G, Fiorelli V, Gendelman R, Morgan RA, Wingfield P, Gallo RC: Release, uptake, and effects of extracellular human immunodeficiency virus type 1 Tat protein on cell growth and viral transactivation. Journal of virology 1993, 67(1):277-287.

91. Peri P, Mattila RK, Kantola H, Broberg E, Karttunen HS, Waris M, Vuorinen T, Hukkanen V: Herpes simplex virus type 1 Us3 gene deletion influences toll-like receptor responses in cultured monocytic cells. Virol J 2008, 5:140.

92. Whitley RJ, Roizman B: Herpes simplex virus infections. Lancet 2001, 357(9267):1513-1518.

93. Miller CS, Danaher RJ, Jacob RJ: Molecular aspects of herpes simplex virus I latency, reactivation, and recurrence. Crit Rev Oral Biol Med 1998, 9(4):541-562.

94. Burgos JS, Ramirez C, Sastre I, Valdivieso F: Effect of apolipoprotein E on the cerebral load of latent herpes simplex virus type 1 DNA. J Virol 2006, 80(11):5383-5387.

95. Wozniak MA, Itzhaki RF, Shipley SJ, Dobson CB: Herpes simplex virus infection causes cellular beta-amyloid accumulation and secretase upregulation. Neurosci Lett 2007, 429(2-3):95-100.

96. Cribbs DH, Azizeh BY, Cotman CW, LaFerla FM: Fibril formation and neurotoxicity by a herpes simplex virus glycoprotein $B$ fragment with homology to the Alzheimer's A beta peptide. Biochemistry 2000, 39(20):5988-5994.

97. Beffert U, Bertrand P, Champagne D, Gauthier S, Poirier J: HSV-1 in brain and risk of Alzheimer's disease. Lancet 1998, 351(9112):1330-1331.

98. Itzhaki RF, Lin WR, Shang D, Wilcock GK, Faragher B, Jamieson GA: Herpes simplex virus type 1 in brain and risk of Alzheimer's disease. Lancet 1997, 349(9047):241-244

99. Itabashi $\mathrm{S}$, Arai H, Matsui T, Higuchi S, Sasaki H: Herpes simplex virus and risk of Alzheimer's disease. Lancet 1997, 349(9058):1102.

100. Letenneur L, Peres K, Fleury H, Garrigue I, Barberger-Gateau P, Helmer C, Orgogozo JM, Gauthier S, Dartigues JF: Seropositivity to herpes simplex virus antibodies and risk of Alzheimer's disease: a population-based cohort study. PLoS One 2008, 3(11):e3637.

101. Burgos JS, Ramirez C, Sastre I, Bullido MJ, Valdivieso F: ApoE4 is more efficient than E3 in brain access by herpes simplex virus type 1 . Neuroreport 2003, 14(14):1825-1827.

102. WuDunn D, Spear PG: Initial interaction of herpes simplex virus with cells is binding to heparan sulfate. J Virol 1989, 63(1):52-58.

103. Koprowski H, Zheng YM, Heber-Katz E, Fraser N, Rorke L, Fu ZF, Hanlon C, Dietzschold B: In vivo expression of inducible nitric oxide synthase in experimentally induced neurologic diseases. Proc Natl Acad Sci USA 1993, 90(7):3024-3027.

104. Meyding-Lamade U, Haas J, Lamade W, Stingele K, Kehm R, Fath A, Heinrich K, Storch Hagenlocher B, Wildemann B: Herpes simplex virus encephalitis: long-term comparative study of viral load and the expression of immunologic nitric oxide synthase in mouse brain tissue. Neurosci Lett 1998, 244(1):9-12.

105. Miyata M, Smith JD: Apolipoprotein E allele-specific antioxidant activity and effects on cytotoxicity by oxidative insults and beta-amyloid peptides. Nat Genet 1996, 14(1):55-61.

106. Lauderback CM, Kanski J, Hackett JM, Maeda N, Kindy MS, Butterfield DA: Apolipoprotein E modulates Alzheimer's Abeta(1-42)-induced oxidative damage to synaptosomes in an allele-specific manner. Brain Res 2002, 924(1):90-97.

107. Colton CA, Brown CM, Cook D, Needham LK, Xu Q, Czapiga M, Saunders AM, Schmechel DE, Rasheed K, Vitek MP: APOE and the regulation of microglial nitric oxide production: a link between genetic risk and oxidative stress. Neurobiology of aging 2002, 23(5):777-785.

108. Picardi A, Gentilucci UV, Bambacioni F, Galati G, Spataro S, Mazzarelli C, D'Avola D, Fiori E, Riva E: Lower schooling, higher hepatitis C virus prevalence in Italy: an association dependent on age. J Clin Virol 2007, 40(2):168-170.

doi:10.1186/1476-511X-9-8

Cite this article as: Kuhlmann et al:. Apolipoprotein E genotype and hepatitis $C$,

HIV and herpes simplex disease risk:

a literature review. Lipids in Health and Disease 2010 9:8.

\section{Submit your next manuscript to BioMed Central and take full advantage of:}

- Convenient online submission

- Thorough peer review

- No space constraints or color figure charges

- Immediate publication on acceptance

- Inclusion in PubMed, CAS, Scopus and Google Scholar

- Research which is freely available for redistribution

Submit your manuscript at www.biomedcentral.com/submit 